\title{
Comments to paper on Radiastraea by Andreas May
}

\author{
TOMASZ WRZOŁEK
}

WrzoŁeK, T. 2007. Comments to paper on Radiastraea by Andreas May. Bulletin of Geosciences 82(3), 297. Czech Geological Survey, Prague. ISSN 1214-1119. Manuscript received April 27, 2007; issued September 30, 2007. DOI 10.3140/bull.geosci.2007.03.297

Tomasz Wrzotek, University of Silesia, Faculty of Earth Sciences, ul. Będzńska 60, PL 41-200 Sosnowiec, Poland; wrzolek@us.edu.pl

It is a good practice to use old paleontological collections for taxonomic revisions, and Andreas May rightly used such material, housed in the Museo Geominero in Madrid (May 2006). On the other hand, however, there are significant risks connected with using museum material and they are clearly seen in his paper.

It should be emphasised, that the type is not only a specimen, but it must be accompanied by exact stratigraphical and geographical data of its sampling location. As it happens so often these data may be missing, dubious or openly false. And it seems this is also the case with Phillipsastrea torreana minuta as revised and presented by May. Knowing that he cannot indicate the precise stratigraphic horizon of the holotype, May decided to select the only existing specimen (at Museo Geominero) as the lectotype, which can be either from the Sta. Lucia Fm. (spanning the Emsian/Eifelian boundary) or from the upper Portilla Fm. (Upper Givetian). As for the taxonomy of this material there is some doubt, because of its poor longitudinal section, which is off-axis. Measurements I have made and comparison with my other material indicate that this colony falls into the variability range for the upper Givetian Phillipsastrea "pradoana", as presented in my recent paper (Wrzołek 2005, table 3, see also remarks at p. 178), with rather thin septa, as opposed to thicker septa of Ph. torreana. My taxonomy is based on 8 specimens from the Cantabrian Mts, so it is probably better than those of May ( 1 specimen) but of course it may not hold when more material becomes available. As it happens, "pradoana" is not a good species name for a Phillipsastrea because, as Coen-Aubert noted (2002, p. 33), the holotype of Acervularia pradoana Haime in de Verneuil \& Barrande is a representative of the genus Argutastrea. So there is a nomenclatorial problem, to find a suitable species to accomodate those phillipsastreids erroneously assigned to Phillipsastrea pradoana, but due to the above-outlined problems with its type material the name $P h$. minuta should not be used at present.

As for Radiastraea arachne as presented by May, I would hesitate to accept if it is conspecific with $R$. arachne, but I have little or no doubt it is not congeneric with Phillipsastrea. Among the phillipsastreid species groups (Wrzołek 2005, p. 164 and the following) somewhat similar are the Famennian species of the Sudetes (Berkowski 2002: Scruttonia kunthi and the other species), lacking the horseshoe dissepiments, with very thin septa and negligible septal expansion, whereas May's material has shorter septa and is of much older age.

It is a pity that Andreas May did not make additional sampling, as it might have allowed him to recognize the original sampling horizon(s) of Almela and Revilla; if done, it might give him more material, and a new perspective of better knowledge of the species studied, the nomenclature, variability, affinities and biogeographic significance. I hope this can and will be done.

\section{References}

BerkowsKi, B. 2002. Famennian Rugosa and Heterocorallia from southern Poland. Palaeontologia Polonica 61, 3-88.

Coen-Aubert, M. 2002. Nouvelles especès du genre Phillipsastrea d'Orbigny près de la limite Givetien-Frasnien dans le Tafilalt et le Ma'ader au Maroc et notes sur des types espagnols. Coral Research Bulletin 7, 21-37.

May, A. 2006. Radiastraea (Anthozoa, Rugosa) from the Emsian and Eifelian (Devonian) of Aviados, northern Spain. Bulletin of Geosciences 81(3), 151-162.

WrzoŁEK, T. 2005. Devonian rugose corals of the Phillipsastrea hennahii species group. Acta Geologica Polonica 55(2), 163-185. 